\title{
PERLAKUAN AKUNTANSI ATAS KONSTRUKSI DALAM PENGERJAAN PADA LAPORAN KEUANGAN PEMERINTAH DAERAH PADA KABUPATEN MINAHASA
}

\author{
Maruli Harry Siregar \\ David P. E. Saerang \\ Fakultas Ekonomi dan Bisnis Magister Akuntansi \\ Universitas Sam Ratulangi Manado \\ email: maruli_regar@yahoo.com
}

\begin{abstract}
This study aimed to assess and provide feedback on the accounting treatment of Construction in Progress which is within the financial statements of Local Government. The analysis method used in this research is to use descriptive analysis method to describes the results of the analysis of the accounting treatment conducted by local government to account Construction in progress.

Construction in progress are fixed assets that are in the process of development. The work includes the construction in the land, equipment and machinery, buildings and buildings, roads, irrigation and networks, and other fixed assets that the process of acquisition and / or construction requires a certain period of time and has not been completed. Listing of construction in progress in Minahasa regency government is done by making an adjustment to the journal reported assets unfinished for later recorded under construction in progress. In the process of recording still no records of advances in the development of an asset. There are some problems that can be encountered by the relevant local government recognition of a construction in progress. Recognition of construction in progress are important things that need to follow the guidelines in the Government Accounting Standards. Above special cases should be given special treatment and separate accounting policies in recognition of Construction in progress.
\end{abstract}

Keywords: Government Accounting, Fixed Assets, Construction in Progress, Financial Statements

\section{PENDAHULUAN}

Sejak terbitnya PP No. 24 tahun 2005, setiap unit pelaporan pada instansi pemerintah wajib untuk menyusun neraca sebagai bagian dari laporan keuangan pemerintah. Pengakuan/pencatatan ,pengukuran/penilaian, dan penyajian serta pengungkapan aset tetap menjadi fokus utama karena aset tetap memiliki nilai yang sangat signifikan dan memiliki tingkat kompleitas yang tinggi.

Salah satu bagian dari akuntansi aset tetap adalah Konstruksi Dalam Pengerjaan yang telah diatur dalam Pernyataan Standar Akuntansi Pemerintahan (PSAP) Nomor 08 dari Lampiran PP 24 Tahun 2005 , maupun PSAP 08 dari Lampiran II PP 71 Tahun 2010 . PSAP 08 tersebut memberikan pedoman bagi pemerintah dalam melakukan pengakuan, pengukuran, dan penyajian serta pengungkapan Konstruksi dalam Pengerjaan berdasarkan peristiwa (events) yang terjadi.Pemahaman tentang Konstruksi Dalam pengerjaan, permasalahan dan solusinya menjadi hal yang sangat penting bagi penyusun laporan keuangan, aparat pengawasan internal pemerintah (APIP) yang melakukan reviu atas laporan keuangan, dan auditor eksternal yang melakukan audit atas laporan keuangan pemerintah baik pusat maupun daerah. Dengan pemahaman yang memadai tentang hal tersebut diharapkan laporan keuangan akan menjadi lebih berkualitas dengan opini wajar tanpa pengecualian.

Beberapa permasalahan terkait Konstruksi dalam Pengerjaan yang akan diulas dalam tulisan ini dengan tujuan untuk memberikan masukan pertimbangan bagi pihak-pihak yang berkepentingan untuk memahami lebih lanjut perlakuan Konstruksi Dalam Pengerjaan dalam laporan keuangan pemerintah. Disini penulis ingin mengetahui dan memberikan tinjauan atas perlakuan Akuntansi pada Laporan Keuangan Pemerintah Daerah dalam kaitannya terhadap pengakuan, penyajian, 
pengungkapan dan pengukuran Konstruksi dalam Pengerjaan sebagai salah satu bagian dari Aset pemerintah daerah.

Berdasarkan latar belakang di atas maka dapat diindentifikasikan rumusan masalah adalah bagaimana perlakuan akuntansi atas konstruksi dalam pengerjaan pada laporan keuangan Pemerintah Kabupaten Minahasa?

Dari perumusan masalah maka yang menjadi tujuan penelitian adalah untuk menganalisis perlakuan akuntansi atas Konstruksi dalam Pengerjaan yang dilakukan oleh Pemerintah Kabupaten Minahasa.

Manfaat yang diharapkan dari penelitan yang dilakukan penulis adalah sebagia berikut.

1. Menambah khazanah empirik terkait dengan perlakuan akuntansi atas konstruksi dalam pengerjaan.

2. Menjadi masukan bagi Pemerintah Kabupaten Minahasa dalam menerapkan akuntansi atas konstruksi dalam pengerjaan.

\section{LANDASAN TEORITIS}

Halim (2007:38) mengemukakan definisi Akuntansi Keuangan Daerah adalah proses pengidentifikasian, pengukuran, pencatatan dan pelaporan transaksi ekonomi (keuangan) dari entitas pemerintah daerah (kabupaten, kota, atau provinsi) yang dijadikan sebagai alat informasi dalam rangka pengambilan keputusan ekonomi oleh pihak-pihak eksternal pemerintah daerah yang memerlukan.

Selanjutnya, Bastian (2001:6) menjelaskan tentang pengertian Akuntansi Sektor Publik adalah sebagai berikut:

“... mekanisme teknik dan analisis akuntansi yang diterapkan pada pengelolaan dana masyarakat di lembaga-lembaga tinggi negara dan departemen-departemen di bawahnya, pemerintah daerah, BUMN, BUMD, LSM dan yayasan sosial, maupun pada proyek-proyek kerjasama sektor publik dan swasta."

Berdasarkan pengertian di atas Akuntansi Pemerintahan adalah akuntansi yang digunakan dalam suatu organisasi pemerintahan / lembaga yang tidak bertujuan untuk mencari laba, dan merupakan suatu bagian dari disiplin ilmu akuntansi sebagai yang utuh.

Berdasarkan PP 71 tahun 2010 Konstruksi Dalam Pengerjaan merupakan bagian dari Aset tetap. Aset tetap adalah aset berwujud yang mempunyai masa manfaat lebih dari dua belas bulan untuk digunakan dalam kegiatan pemerintah atau dimanfaatkan oleh masyarakat umum. Komponen Aset tetap antara lain sebagai berikut.

1. Tanah.

2. Peralatan dan mesin.

3. Gedung dan bangunan.

4. Jalan, irigasi, dan jaringan

5. Aset tetap lainnya.

6. Konstruksi dalam pengerjaan.

Konstruksi dalam pengerjaan adalah aset-aset tetap yang sedang dalam proses pembangunan. Konstruksi Dalam Pengerjaan mencakup tanah, peralatan dan mesin, gedung dan bangunan, jalan, irigasi dan jaringan, dan aset tetap lainnya yang proses perolehannya dan/atau pembangunannya membutuhkan suatu periode waktu tertentu dan belum selesai. Perolehan melalui kontrak konstruksi pada umumnya memerlukan suatu periode waktu tertentu. Periode waktu perolehan tersebut bisa kurang atau lebih dari satu periode akuntansi.

Suatu benda berwujud harus diakui sebagai Konstruksi Dalam Pengerjaan jika memenuhi kondisi berikut ini.

1. Besar kemungkinan bahwa manfaat ekonomi masa yang akan datang berkaitan dengan aset tersebut akan diperoleh.

2. Biaya perolehan tersebut dapat diukur secara andal.

3. Aset tersebut masih dalam proses pengerjaan. 
Konstruksi Dalam Pengerjaan dicatat dengan biaya perolehan. Nilai konstruksi yang dikerjakan oleh kontraktor melalui kontrak konstruksi meliputi berikut ini.

1. Termin yang telah dibayarkan kepada kontraktor sehubungan dengan tingkat penyelesaian pekerjaan.

2. Kewajiban yang masih harus dibayar kepada kontraktor berhubung dengan pekerjaan yang telah diterima tetapi belum dibayar pada tanggal pelaporan.

3. Pembayaran klaim kepada kontraktor atau pihak ketiga sehubungan dengan pelaksanaan kontrak konstruksi.

Suatu entitas harus mengungkapkan informasi mengenai Konstruksi Dalam Pengerjaan pada akhir periode akuntansi untuk hal-hal berikut ini.

1. Rincian kontrak konstruksi dalam pengerjaan berikut tingkat penyelesaian dan jangka waktu penyelesaiannya.

2. Nilai kontrak konstruksi dan sumber pembiayaanya.

3. Jumlah biaya yang telah dikeluarkan.

4. Uang muka kerja yang diberikan.

5. Retensi.

Dalam penelitian ini, yang menjadi obyek penelitian adalah Pemerintah Kabupaten Minahasa pada LKPD TA 2013. Metode analisis dalam penelitian ini adalah dengan menggunakan metode analisis deskriptif. Metode analisis deskriptif adalah suatu metode penelitian yang menguraikan hasil analisis perlakuan akuntansi yang dilakukan oleh Pemerintah daerah terhadap akun Konstruksi dalam pengerjaan.

\section{HASIL PENELITIAN dan PEMBAHASAN MASALAH}

Pada Catatan atas Laporan Keuangan Konstruksi Dalam Pengerjaan Kabupaten Minahasa Diungkapkan hal-hal sebagai berikut. Saldo KDP pada Tahun 2013 adalah sebesar Rp 14.340.980.822,00 dan pada Tahun 2012 sebesar Rp10.864.694.322,00 .

Penyusunan Laporan Keuangan untuk tahun yang berakhir 31 Desember 2013 berdasarkan asumsi sebagai berikut.

1. Pemerintah Kabupaten Minahasa merupakan organisasi yang mandiri dan harus bertanggung jawab atas pelaksanaan tugasnya sesuai dengan peraturan perundangundangan yang berlaku atau sebagai entitas akuntansi.

2. Pemerintah Kabupaten Minahasa akan berlanjut keberadaannya atau berkesinambungan.

3. Setiap kejadian atau transaksi yang disajikan dalam laporan keuangan dapat dinilai dengan satuan uang, berdasarkan asumsi keterukuran dalam satuan mata uang.

Laporan Keuangan Tahun 2013 Pemerintah Kabupaten Minahasa mengacu pada Peraturan Pemerintah Nomor 71 Tahun 2010 tentang Standar Akuntansi Pemerintah Lampiran I. Basis akuntansi yang digunakan dalam laporan keuangan pemerintah Kabupaten Minahasa adalah basis kas untuk pengakuan pendapatan, belanja, dan pembiayaan dalam Laporan Realisasi Anggaran, dan basis akrual untuk pengakuan aset, kewajiban, dan ekuitas dalam Neraca. Basis akrual untuk Neraca berarti bahwa aset, kewajiban, dan ekuitas dana diakui dan dicatat pada saat terjadinya transaksi, atau pada saat kejadian atau kondisi lingkungan berpengaruh pada keuangan pemerintah, tanpa memperhatikan saat kas atau setara kas diterima atau dibayar.

Pada lampiran X pernyataan SAP nomor 8 disebutkan bahwa Konstruksi Dalam Pengerjaan mencakup tanah, peralatan dan mesin, gedung dan bangunan, jalan, irigasi dan jaringan, dan aset tetap lainnya yang proses perolehannya dan/atau pembangunannya membutuhkan suatu periode wa ktu tertentu dan belum selesai. Perolehan melalui kontrak konstruksi pada umumnya memerlukan suatu periode waktu tertentu. Periode waktu perolehan tersebut bisa kurang atau lebih dari satu periode akuntansi. Perolehan aset dapat dilakukan dengan membangun sendiri (swakelola) atau melalui pihak ketiga dengan kontrak konstruksi. 
Pemerintah daerah dalam pengelolaan keuangan mengacu kepada permendagri 13 tahun 2006 dan perubahannya. Pada Kabupaten Minahasa Pencatatan akuntansi atas semua transaksi keyangan dilakukan dengan bantuan sistem informasi berupa SIMDA (Sistem Informasi Manajamen Daerah). Secara sistem SIMDA belum dapat mencatat pengeluaran untuk belanja aset tetap yang dilakukan melalui belanja modal dikolorarikan kepada KDP melainkan dikolorarikan kepada masing-masing akun aset tetap selain KDP.

Aset harus diakui sebagai KDP jika: a. besar kemungkinan bahwa manfaat ekonomi masa yang akan datang berkaitan dengan aset tersebut akan diperoleh; b. biaya perolehan aset tersebut dapat diukur dengan handal; c. aset tersebut masih dalam proses pengerjaan. Apabila dalam konstruksi aset tetap pembangunan fisik proyek belum dilaksanakan, namun biaya-biaya yang dapat diatribusikan langsung ke dalam pembangunan proyek telah dikeluarkan, maka biaya-biaya tersebut harus diakui sebagai KDP aset yang bersangkutan Konstruksi secara substansi telah selesai dikerjakan dan konstruksi tersebut telah dapat memberikan manfaat/jasa sesuai tujuan perolehan. Dokumen sumber untuk pengakuan penyelesaian suatu KDP adalah Berita Acara Penyelesaian Pekerjaan (BAPP). Dengan demikian, apabila atas suatu KDP telah diterbitkan BAPP, berarti pembangunan tersebut telah selesai. Selanjutnya, aset tetap definitif sudah dapat diakui dengan cara memindahkan KDP tersebut ke akun aset tetap yang bersangkutan

Pada pemerintah daerah Kabupaten minahasa KDP diungkapkan sesuai nilai dari kontrak yang telah dibayarkan. Pada Kabupaten Minahasa secara umum aset yang diakui sebagai KDP adalah Pembagunan Tahap I sd III Benteng Moraya dan Pekerjaan Konsultansi Perencanaan dan Pelaksanaan atas aset-aset yang telah dibangun dan yang akan dibangun.

Pengakuan KDP atas aset pembangunan Benteng Moraya dicatat dalam 3 jenis aset yang berbeda yaitu sebagai berikut.

1. Pembangunan Fisik Tahap I Benteng Moraya Kontrak No. 166/PU/SP/2011 tanggal 17 Oktober 2011 Rp2.288.610.000,00.

2. Pembangunan Fisik Tahap II Benteng Moraya Kontrak No. 035/PU/SP/2012 tanggal 5 Maret 2012 senilai Rp1.720.620.000,00.

3. Pembangunan fisik Benteng Moraya Tahap III Dinas Pariwisata dan Kebudayaan No. 01/PARBUD/SP/II/2013 tanggal 1 Mei 2013 senilai Rp964.887.000,00.

Aset KDP yang berasal dari Kontrak konsultansi atas aset yang dibangun adalah perencanaan dan pengawasan Benteng Moraya yaitu sebagai berikut.

1. Perencanaan Teknis Benteng Moraya Tahap I Tahun 2011 (No.269/SPK/PU/2011 tanggal 9 September 2011 senilai Rp49.575.000,00.

2. Pengawasan Pembangunan Benteng Moraya Tahap I Tahun 2011 Kontrak No. 241/PU/SP/2011 tanggal 17 Oktober 2011 senilai Rp79.250.000,00.

3. Pengawasan Pembangunan Benteng Moraya Tahap II Tahun 2011 Kontrak No. 258/PU/SP/2011 tanggal 30 November 2011senilai Rp96.000.000,00.

4. Konsultasi Pengawasan Benteng Moraya Tahap II No. 264/PU/SP/2012 tanggal 15 Maret 2012 senilai Rp59.000.000,00.

5. Perencanaan Bangunan Benteng Moraya Tahap III Dinas Pekerjaan Umum No. 872/SPK.PL.CK/PjP/XI/2013 senilai Rp49.650.000,00.

Pada laporan Keuangan Kabupaten Minahasa tahun 2013 hal - hal yang diungkapkan dalam penjelasan CaLK untuk akun Konstruksi dalam pengerjaan adalah sebagai berikut.

1. Saldo akun Konstruksi dalam Pengerjaan tahun 2013 dan 2012.

2. Mutasi konstruksi dalam pengerjaan baik penambahan maupun pengurangan.

3. Nama aset-aset konstruksi dalam pengerjaan.

4. Nilai masing-masing aset konstruksi dalam pengerjaan.

Pemerintah daerah dalam pengelolaan keuangan mengacu kepada permendagri 13 tahun 2006 dan perubahannya. Pada Kabupaten Minahasa Pencatatan akuntansi atas semua transaksi keyangan dilakukan dengan bantuan sistem informasi berupa SIMDA. Seperti dijelaskan diatas terdapat 
kelemahan dalam proses pencatatan akuntansi dengan menggunakan SIMDA yaitu belanja modal langsung kolorarikan sebagai aset tetap dari akun belanja modal tersebut. Pencatatan tersebut tidak tetap karena sesuai SAP lampiran 7 Tentang akuntansi aset tetap dijelaskan bahwa Untuk dapat diakui sebagai aset tetap, suatu aset harus berwujud dan memenuhi criteria sebagai berikut.

1. Mempunyai masa manfaat lebih dari 12 (dua belas) bulan.

2. Biaya perolehan aset dapat diukur secara andal.

3. Tidak dimaksudkan untuk dijual dalam operasi normal entitas.

4. Diperoleh atau dibangun dengan maksud untuk digunakan.

Berdasarkan kiretria pengakuan aset tetap tersebut maka seharusnya belanja modal aset gedung bangunan tidak langsung dikolorarikan menjadi aset tetap karena belanja modal yang dibayarkan belum menghasilkan aset tetap yang berwujud dan mempunyai masa manfaat lebih dari 12 (dua belas) bulan. Seharusnya pencatatan belanja modal dikolorarikan ke KDP terlebih dahulu.

Sehingga pada akhir tahun tidak perlu dilakukan jurnal penyesuaian oleh pemerintah daerah. Selain itu pada pengungkapan atas Konstruksi dalam pengerjaan disyaratkan untuk mengungkapkan Uang muka kerja yang diberikan sampai dengan tanggal neraca namun pemerintah daerah umumnya tidak mencatat atas pemberian uang muka tersebut.

Berdasarkan Perpres 54 tahun 2010 dan perubahannya tentang pengadaan barang dan jasa pemerintah penyedia jasa pemerintah dapat diberikan uang muka kerja yang besarannya setinggitingginya 30\% dari nilai kontrak untuk usaha kecil dan setinggi-tingginya $20 \%$ dari nilai kontrak untuk usaha non kecil. Penyelesaian uang muka dari penyedia jasa diperhitungkan dalam setiap termin pembayaran secara proporsional sesuai dengan pencapaian prestasi pekerjaan sehingga pembayaran prestasi kerja diberikan kepada Penyedia Barang/Jasa setelah dikurangi angsuran pengembalian Uang Muka dan bila terjadi. Dalam hal terjadi pemutusan Kontrak yang dilakukan karena kesalahan Penyedia Barang/Jasa maka b.sisa Uang Muka harus dilunasi oleh Penyedia Barang/Jasa atau Jaminan Uang Muka dicairkan.

Dalam pencatatan akuntansi yang dilakukan oleh pemerintah daerah tidak terdapat pencatatan atas uang muka. Permendagri 13 tahun 2006 dan perubahannya tidak mengatur pengelolaan uang muka kerja atas proyek konstruksi. Uang muka kerja dapat diibaratkan sebagai pinjaman yang diberikan oelh pemerintah daerah kepada penyedia jasa konstruksi. Untuk akuntansi tentang pinjaman SAP mengaturnya untuk dicatat pada pembiayaan di LRA dan LAK.

Ketiadaan pencatatan atas pemberian uang muka kerja akan mempengaruhi dalam penyajian laporan keuanga pemerintah daerah sebagai berikut.

1. Terhadap proyek rampung dalam satu tahun anggaran baik secara fisik maupun secara administrasi/keuangan, ketiadaan pencatatan akan berpengaruh kepada LRA dan LAK berupa hilangnya informasi pemberian piutang uang muka kerja dan penyelesaiannya.

2. Terhadap proyek yang tidak dapat diselesaikan pembayarannya dalam tahun anggaran bekenaan terlepas apakah secara fisik proyek tersebut telah selesai atau belum selesai. Ketiadaan pencatatan uang muka kerja akan mempengaruhi neraca disebabkan tidak adanya pencatatan secara wajar atas saldo piutang kepada pihak ke III serta akan mengurangi pengungkapan atas KDP dapa Catatan atas Laporan Keuangan.

Berdasarkan PSAP 08 Paragraf 13, suatu benda berwujud harus diakui sebagai KDP jika keadaan berikut

1. Besar kemungkinan bahwa manfaat ekonomi masa yang akan datang berkaitan dengan aset tersebut akan diperoleh.

2. Biaya perolehan aset tersebut dapat diukur dengan handal.

3. Aset tersebut masih dalam proses pengerjaan.

Apabila dalam konstruksi aset tetap pembangunan fisik proyek belum dilaksanakan, namun biaya-biaya yang dapat diatribusikan langsung ke dalam pembangunan proyek telah dikeluarkan, maka biaya-biaya tersebut harus diakui sebagai KDP aset yang bersangkutan 
Pada Konstruksi dalam pengerjaan di Kabupaten Minahasa terdapat aset-aset berupa benteng moraya yang telah dibangun dalam 3 tahap dan setiap tahap dikontrakkan dam perjanjian konstruksi yang terpisah dan berdiri sendiri dan didukung perjanjian perencanaan dan pengawasan yang juga berdiri sendiri. Atas gedung bangunan benteng moraya yang kontraknya telah selesai tetap dikategorikan sebagai konstruksi dalam pengerjaan karena belum dimanfaatkan, namun atas hal tersebut tidak cukup diungkapkan oleh pemerintah Kabupaten Minahasa.

Sesuai dengan paragraf 15 PSAP 08, suatu KDP akan dipindahkan ke pos aset tetap yang bersangkutan jika konstruksi secara substansi telah selesai dikerjakan dan konstruksi tersebut telah dapat memberikan manfaat/jasa sesuai tujuan perolehan. Dokumen sumber untuk pengakuan penyelesaian suatu KDP adalah Berita Acara Penyelesaian Pekerjaan (BAPP). Dengan demikian, apabila atas suatu KDP telah diterbitkan BAPP, berarti pembangunan tersebut telah selesai. Selanjutnya, aset tetap definitif sudah dapat diakui dengan cara memindahkan KDP tersebut ke akun aset tetap yang bersangkutan. Pencatatan suatu transaksi perlu mengikuti sistem akuntansi yang ditetapkan dengan pohon putusan (decision tree) sebagai berikut.

1. Atas dasar bukti transaksi yang obyektif (objective evidences).

2. Dalam hal tidak dimungkinkan adanya bukti transaksi yang obyektif maka digunakan prinsip subtansi mengungguli bentuk formal (substance over form).

Selain itu pada KDP Pemerintah Kabupaten Minahasa terdapa aset KDP berupa Jasa Konsultansi Perencanaan pembangunan aset Tetap yang terdiri dari 6 aset KDP. Hal tersebut sejalan dengan Bultek 9 tentang aset tetap pada contoh kasus tentang pengakuan Biaya Perencanaan. Pelaksanaan pembagunan aset tetap yang dapat menyebabkan terjadinya KDP sering ditemui beberapa kondisi yang berbeda terkait tingkat penyelesaian pekerjaan konstruksi dan realisasi pembayarannya diantaranya sebagai berikut.

1. Tingkat penyelesaian pekerjaan (fisik) adalah $100 \%$, dan realisasi pembayaran sebesar $100 \%$ dari nilai kontrak. Apabila pekerjaan konstruksi telah selesai (fisik 100\%) dan telah diserahkan berdasarkan dokumen PHO. Dalam kondisi seperti ini KDP diakui sebesar termin yang telah dibayarkan kepada kontraktor sehubungan dengan tingkat penyelesaian pekerjaan atau sebesar pembayaran sesuai nilai kontrak konstruksi. Selanjutnya KDP dialihkan ke aset tetap definitifnya. Hal ini merupakan kejadian ideal yang seharusnya terjadi pada kontrak konstruksi pada pemerintah daerah.

2. Tingkat penyelesaian pekerjaan adalah $100 \%$, dan realisasi pembayaran sebesar $95 \%$ (retensi sebesar 5\% ditahan pembayarannya sampai berakhirnya masa pemeliharaan).Apabila pekerjaan konstruksi sebenarnya telah selesai (fisik 100\%) dan telah diserahkan berdasarkan dokumen PHO, namun terdapat retensi sebesar 5\% dari nilai kontrak, sehingga hanya dibayarkan sebesar 95\% dari nilai kontrak. Dalam kondisi seperti ini KDP diakui sebesar nilai kontrak dengan berdasarkan pada tingakt penyelesaiannya. Selanjutnya KDP dialihkan ke aset tetap definitifnya. Retensi sebesar 5\% dari nilai kontrak diakui sebagai utang jangka pendek dan dianggarkan dalam APBD tahun berikutnya pada pos pengeluaran pembiayaan.

3. Tingkat penyelesaian pekerjaan adalah $100 \%$, dan realisasi pembayaran lebih kecil dari tingkat penyelesaian pekerjaan. Apabila pekerjaan konstruksi telah selesai (fisik 100\%) dan telah diserahkan berdasarkan dokumen PHO, namun pembayaran lebih kecil dari tingkat penyelesaian pekerjaannya. Dalam kasus seperti ini KDP diakui sebesar nilai kontrak karena pekerjaan telah selesai. Selanjutnya KDP dialihkan ke aset tetap definitifnya karena telah selesai, diserahkan, dan dapat digunakan. Sisa pembayaran diakui sebagai utang jangka pendek di neraca dan dianggarkan dalam APBD tahun berikutnya pada pos pengeluaran pembiayaan.

4. Tingkat penyelesaian pekerjaan adalah kurang dari $100 \%$ (misalkan $70 \%$ ), dan realisasi pembayaran adalah sesuai dengan tingkat penyelesaian pekerjaannya. Apabila pekerjaan konstruksi belum selesai realisasi fisik $70 \%$ sehingga KDP diakui sebesar termin yang telah dibayarkan kepada kontraktor sehubungan dengan tingkat penyelesaian pekerjaan sebesar $70 \%$ dari nilai kontrak. Dalam kasus seperti ini KDP diakui sebesar nilai kontrak karena pekerjaan telah selesai. 
5. Tingkat penyelesaian pekerjaan adalah kurang dari 100\% (misalkan $70 \%$ ), namun realisasi pembayarannya lebih kecil dari tingkat penyelesaian pekerjaan yaitu baru dibayarkan sebesar $60 \%$ dari nilai kontrak. Apabila pekerjaan konstruksi belum selesai dalam hal ini 70\%), namun pembayaran lebih kecil dari tingkat penyelesaian pekerjaannya. Dalam kasus seperti ini KDP diakui sebesar termin yang telah dibayarkan kepada kontraktor $(60 \%)$ ditambah dengan kewajiban yang masih harus dibayar kepada kontraktor berhubung dengan pekerjaan yang telah diterima tetapi belum dibayar pada tanggal pelaporan (10\% dari nilai kontrak). Sisa pembayaran sebesar 10\% diakui sebagai utang jangka pendek di neraca.

6. Pekerjaan konstruksi baru mencapai tingkat penyelesaian sebesar $60 \%$, tetapi realisasi pembayarannya sebesar $70 \%$ dari nilai kontrak. Apabila pekerjaan konstruksi belum selesai dalam hal ini $60 \%$, namun pembayaran lebih besar dari tingkat penyelesaian pekerjaannya. Dalam kasus seperti ini KDP diakui sebesar termin yang telah dibayarkan kepada kontraktor (70\%). Kelebihan pembayaran sebesar $10 \%$ diakui sebagai piutang kepada pihak Ke III di neraca.

Pemerintah daerah Kabupaten Minahasa dalam Catatan atas laporan Keuangan menjelaskan secara minimal atas akun Konstruksi dalam pengerjaan. Pemerintah kabupaten Minahasa hanya menjelaskan nama atas aset konstruksi dalam pengerjaan dan nilai dari aset tersebut. Pemerintah Daerah Kabupaten Minahasa seharusnya menambahkan beberapa keterangan lain seperti yang disyarakan oleh Standar akuntansi Pemerintah yaitu sebagai berikut.

1. Rincian kontrak konstruksi dalam pengerjaan berikut tingkat penyelesaian dan jangka waktu penyelesaiannya pada tanggal neraca.

2. Nilai kontrak konstruksi dan sumber pembiayaanya.

3. Jumlah biaya yang telah dikeluarkan sampai dengan tanggal neraca.

4. Uang muka kerja yang diberikan sampai dengan tanggal neraca.

5. Jumlah Retensi.

Pemerintah Kabupaten Minahasa mengungkapkan dalam Catatan atas Laporan Keuangan terdapat 15 aset Konstruksi dalam Pengerjaan. Namun didalamnya terdapat aset konstruksi dalam pengerjaan berupa benteng moraya yang merupakan satu kesatuan aset namun dicatat sebagai 8 aset mandiri

Tambahan pengungkapan berupa penyatuan nilai aset KDP serta jumlah aset tersebut akan meningkatkan nilai informasi dari laporan keuangan karena akan menghindari penggunan laporan keuangan agar tidak salah menilai atas nilai keseluruhan suatu aset KDP serta tidak menyesatkan atas banyaknya aset KDP yang dimiliki. Pengungkapan atas hal-hal tersebut akan memudahkan dalam penjelasan dan dalam membandingkan laporan keuangan. Pemerintah daerah diharapkan dapat mengidentifikasi kebijakan akuntansi tambahan dan pengungkapan yang mendorong pemerintah daerah untuk meningkatkan akuntabilitas keuangan dan transparansi laporan keuangan. Hal tersebut diantaranya mencakup penjelasan tentang metode alternatif untuk menyajikan informasi tertentu.

\section{KESIMPULAN DAN SARAN}

Pencatatan konstruksi dalam pengerjaan pada pemerintah Kabupaten Minahasa dilakukan dengan cara membuat jurnal penyesuaian atas aset-aset yang dilaporkan belum selesai untuk kemudian dicatat pada akun Konstruksi dalam pengerjaan. Pemerintah Kabupaten Minahasa dalam pengakuan KDP masih mencatat beberapa kontrak atas pembangunan benteng Moraya ke dalam beberapa aset yang berbeda walaupun KDP tersebut merupakan satu kesatuan Aset. Pemerintah Kabupaten Minahasa belum mengungkapkan secara memadai atas persyaratan KDP seperti yang terdapat dalam Standar akuntansi Pemerintahan.

Pada proses pencatatan masih belum ada pencatatan atas uang muka dalam pembangunan suatu aset. Terdapat beberapa permasalahan yang dapat dihadapi oleh pemerintah daerah terkait pengakuan suatu Konstruksi dalam pengerjaan. Pengakuan konstruksi dalam pengerjaan adalah hal penting dimana perlu untuk mengikuti panduan dalam Standar akuntansi Pemerintahan. Pada akhirnya Pengakuan Konstruksi dalam pengerjaan yang tepat akan membantu pemerintah daerah dalam pengungkapan di Laporan Keuangan. Pada akhirnya akan menyajikan nilai aset secara wajar. 
Dari kesimpulan tersebut diatas maka dapat diberikan beberapa saran sebagai berikut:

1. Pemerintah daerah Kabupaten Minahasa dapat memperbaiki sistem informasi yang digunakan sehingga dapat mencatat Belanja modal terlebih dahulu sebagai aset konstruksi dalam pengerjaan untuk kemudian saat pekerjaan selesai dapat diakui sebagai aset definitive. Perbaikan sistem juga dapat digunakan untuk mencata pengeluaran sebagai uang muka pekerjaan dari kontrak Konstruksi. Atas kasus-kasus khusus hendaknya diberikan perlakuan khusus dan kebijakan akuntansi tersendiri didalam pengakuan dari Konstruksi dalam pengerjaan.sehingga Pemerintah daerah memiliki panduan yang konsisten atas suatu kejadian akuntansi.

2. Penelitian ini tidak membahas konstruksi dalam pengerjaan yang ditujukan menjadi aset tetap tanah, aset tetap peralatan dan mesin, aset tetap Jalan Irigasi dan Jaringan serta aset tetap lainnya. Semoga dimasa yang akan datang terdapat penelitian yang membahas kasus dan kebijakan akuntansi atas hal tersebut.

\section{DAFTAR PUSTAKA}

Halim, Abdul, Akuntansi Keuangan Daerah, Edisi Ketiga, Salemba Empat, Jakarta, 2007.

Mahmudi, Analisis Laporan Keuangan Pemerintah Daerah, Unit Penerbit dan Percetakan STIM YKPN, Yogyakarta, 2009.

Peraturan Pemerintah Republik Indonesia Nomor 105 Tahun 2000, Pengelolaan dan

Pertanggungjawaban Keuangan Daerah, Jakarta, 2000.

Peraturan Pemerintah Republik Indonesia Nomor 58 Tahun 2005, Pengelolaan Keuangan Daerah, Jakarta, 2005.

Peraturan Pemerintah Nomor 24 Tahun 2005, Standar Akuntansi Pemerintahan, Jakarta, 2005.

Peraturan Pemerintah Nomor 71 Tahun 2010, Standar Akuntansi Pemerintahan, Jakarta, 2010.

Peraturan Menteri Dalam Negeri Nomor 13 Tahun 2006, Pedoman Pengelolaan Keuangan Daerah, Jakarta, 2006.

Sugiyono, 2012, Metode Penelitian Kombinasi (Mixed Method), Alfabeta, Jakarta.

Undang-Undang Nomor 33 Tahun 2004, Perimbangan Keuangan Antara Pemerintah Pusat dan

Daerah, Jakarta, 2004. 